Research Article

\title{
Study on Flexural Behaviour of Box Section Bamboo-Steel Composite Beams
}

\author{
Qifeng Shan $\mathbb{D}^{1,2}$ Jialiang Zhang, ${ }^{2}$ Keting Tong, ${ }^{2}$ and Yushun Li $\mathbb{D}^{3}$ \\ ${ }^{1}$ Zhejiang Industry Polytechnic College, Shaoxing 312000, China \\ ${ }^{2}$ School of Civil and Environmental Engineering, Ningbo University, Ningbo 315211, China \\ ${ }^{3}$ College of Civil Engineering \& Architecture, Qingdao Agricultural University, Qingdao 266109, China \\ Correspondence should be addressed to Yushun Li; lys0451@163.com
}

Received 27 July 2020; Revised 23 September 2020; Accepted 28 October 2020; Published 17 November 2020

Academic Editor: Dongsheng Huang

Copyright (C) 2020 Qifeng Shan et al. This is an open access article distributed under the Creative Commons Attribution License, which permits unrestricted use, distribution, and reproduction in any medium, provided the original work is properly cited.

To take full advantages of the bamboo and cold-formed thin-walled steel, a new type of box section beam combined with bamboo and steel channel was proposed in this paper. Five composite beams with different parameters were tested to evaluate the effects of bamboo plywood thickness of composite beams and thickness and sectional dimension of steel channel. The results of experiment showed that the proposed composite beams exhibited excellent flexural bearing capacities and stiffness. The increase of bamboo plywood thickness and sectional dimension of steel channel could improve bearing capacity and flexural stiffness of composite beams, while the increase of steel thickness could enhance the bearing capacity and safety margin of composite beams. Furthermore, a new method to predict the deformation and bearing capacities of composite beams was proposed and matched well with the experimental results.

\section{Introduction}

With the development of the society, green, sustainable, and ecologically materials are required to be employed for the construction. Wood and bamboo are one of environmentfriendly building materials. Furthermore, wood and bamboo have the advantages of light weight, high strength, and good seismic resistant performance as construction materials.

However, the resources of wood are relatively rare all over the world due to the long growth cycle; thus, the usage of wood is limited. A more environment-friendly building material such as bamboo need to be developed to replace wood.

Bamboo, which has good mechanical performance, has been used by humans for thousands of years. In addition, China has a very rich resource of bamboo [1]. However, the applications of raw bamboo material are limited in civil engineering due to its dimensional instability, irregular shape, and difficult connection [2]. With the development of processing technic, bamboo plywood can be made with good mechanical properties by modified processing of raw bamboo [3-5]. However, the structure members made by modified bamboo had lower bearing capacity compared with the steel members under the same dimensions $[6,7]$, which meant bamboo members needed more materials to attain the same bearing capacity. Therefore, the bamboo structure members strengthened by other materials such as steel bars $[8,9]$, fiber polymer [10], and FRP sheets or grid [11-14] were designed and investigated in the recent years.

Thin-walled cold-formed steel is one of the common construction materials with ultrahigh strength, while the steel members generally cannot reach its ultimate strength due to the buckling. Based on these considerations, a new bamboo-steel composite structure is proposed. The bamboosteel composite structure is made up of bamboo plywood and cold-formed thin-walled steel through epoxy resin. The bamboo-steel composite structure can take the advantages of light weight and high strength of the two materials, while avoiding the disadvantages of easy buckling of cold-formed thin-walled steel. The research studies had showed the cooperation of the two materials could effectively improve the mechanical performance of the composite members [15-19]. 
In this study, a new type of box section bamboo-steel composite beam, which consisted of four pieces of bamboo plywood and two pieces of cold-formed thin-walled steel channel, is proposed. Then, five composite beams proposed above were tested. The flexural behaviours of the composite beams were analysed and compared. The influence of the bamboo plywood thickness and the thickness and sectional dimension of steel channel were also studied in this paper.

\section{Experiment Programs and Results}

2.1. Material Properties. Cold-formed thin-walled steel employed in this paper was made of steel sheets, which were processed by a professional steel structure factory. The thickness $\left(t_{s}\right)$, yield stress $\left(f_{y}\right)$, ultimate stress $\left(f_{u}\right)$, and Young's modulus $\left(E_{s}\right)$ of steel sheets were measured according to [20], as shown in Figure 1(a). The mechanical properties of the steel are listed in Table 1.

There is no material test standard to be made for bamboo plywood in China; hence, the modulus of elasticity $\left(E_{b}\right)$ and the modulus of rupture $(\sigma)$ of bamboo plywood were measured according to the standard of wood-based panels [21], which is shown in Figure 1(b). The mechanical properties of bamboo plywood are listed in Table 2.

2.2. Test Specimens. The main design parameters of box section bamboo-steel composite beams were thickness of bamboo plywood and thickness and sectional dimension of thin-walled steel channel. B-1 and B-2 were designed to investigate the influence of bamboo plywood thickness. B-3 and B-4 were designed to study the effect of steel channel thickness of composite beams. To investigate the effect of steel channel dimension, B-5 was designed as a comparison with B-3. The thickness of bamboo plywood $\left(t_{b}\right)$ was $15.1 \mathrm{~mm}, 17.6 \mathrm{~mm}$, and $25.0 \mathrm{~mm}$, and the thickness of thinwalled steel channel, namely, $t_{s}$ (both web and flange), was $1.35 \mathrm{~mm}$ and $1.75 \mathrm{~mm}$, and dimensions of steel channel cross-section (flange width $\times$ web height, $b_{s} \times h_{s}$ ) were $30 \mathrm{~mm} \times 135 \mathrm{~mm}, \quad 40 \mathrm{~mm} \times 135 \mathrm{~mm}$, and $40 \mathrm{~mm} \times 175 \mathrm{~mm}$, respectively. The length of five specimens (B-1 to B-5) was designed as $2.44 \mathrm{~m}$, while the calculated $\operatorname{span}(l)$ of specimens was $2.2 \mathrm{~m}$. The section of the composite beam is exhibited in Figure 2, and the parameters of specimens are listed in Table 3.

2.3. Specimen Preparation. The box section bamboo-steel composite beams consist of two cold-formed thin-walled steel channel and four bamboo plywood, which is bonded with epoxy resin. The section form of composite beams is shown in Figure 2 and the specific manufacturing processes are as follows. First, polish the interface between thin-walled steel and bamboo plywood to remove zinc coating layer of steel and glaze layer of bamboo plywood. Then, wipe the polished steel and bamboo plywood with alcohol pads to ensure the bonding surface clean. After that, apply the epoxy resin evenly on the surface of bamboo plywood and fix the bamboo plywood and the steel channel with fixtures to make sure that two materials are bonded effectively. Besides, symmetrically place heavy objects on the bond surface to improve the quality of bond. The pressurization process lasted for two days and the curing time lasted for 7 days. The finished specimens are shown in Figure 3.

2.4. Test Setup and Instrumentation. A four-axis universal testing machine was adopted in this study, as shown in Figure 4(a). The mechanical jack was applied for monotonous gradation loading with the step of $5 \mathrm{kN}$. The force sensor was employed to measure the compressive load. Specimens can still bear load after local failure because of good entirety, and the test was terminated when the beam cannot bear higher level load. The four-point flexure loading scheme was adopted. Clear distance between two supports was $2.2 \mathrm{~m}$, two equivalent loading points were $800 \mathrm{~mm}$ from the end of beam, and length of pure bending sections was $600 \mathrm{~mm}$.

Five strain gauges were evenly arranged at the web of midspan of beam. Displacement sensors were installed at support point, loading point, midspan, and midpoint between the support and the loading point to measure vertical deflection under the load. Figure 4(b) shows the scheme of loading device of the test.

Data of strain gauges and displacement sensors was collected by the static strain test system. The load was supposed to be stable in the reading and observation process, and data collection should be carried out after the instrument readings were stable.

\section{Test Results and Discussion}

3.1. Failure Characteristics and Test Observations. All the five specimens showed the similar failure modes. The failure processes for specimen could be divided into two stages. The first stage began with the application of load. As the load increased to about $50 \%$ of the ultimate load, the sporadic sound could be heard due to the extrusion and tension of bamboo plywood. However, no crack could be found on the surface during the first stage. During the second stage, initial debonding cracks could be observed with slight degumming sound in the interface between thin-walled steel and bamboo plywood. With the increase of applied load, the cracks continued to appear and propagated along the interface. As the load was about to reach the ultimate load, the specimens failed due to the local damage and debonding between bamboo plywood and steel channel. However, no overall debonding could be found during the experiment.

Figure 5 shows the failure characteristics of specimens. The difference between B-1 and B-2 is the thickness of bamboo plywood. B-1 failed due to the extrusion of upper bamboo flange (Figure 5(a)), while the upper bamboo flange of B-2 could bear more pressure with thicker bamboo plywood. Debonding at upper flange near the support could be observed when B-2 failed (Figure 5(b)). The difference between B-3 and B-4 is the thickness of steel channel, while they exhibited the similar failure characteristics, both of them failed due to the extrusion of bamboo plywood and local buckling of steel channel in the compression zone of 


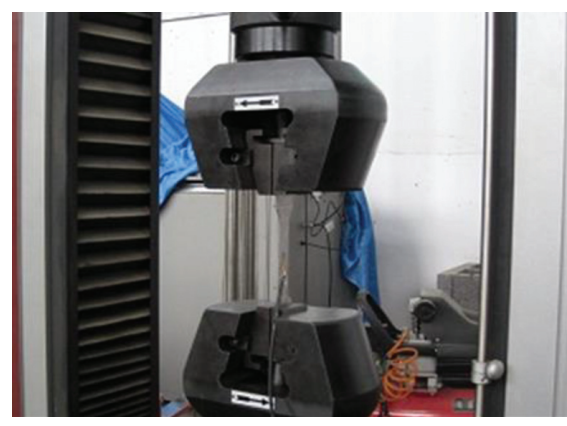

(a)

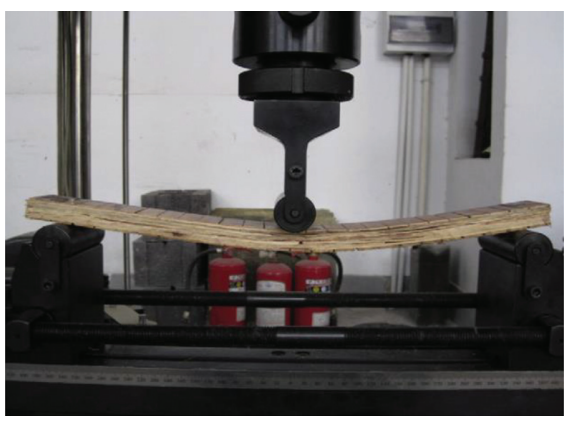

(b)

Figure 1: Test of material properties. (a) Test for steel sheet. (b) Test for bamboo plywood.

TABLE 1: Material properties of cold-formed thin-walled steel.

\begin{tabular}{lccc}
\hline$t_{s}(\mathrm{~mm})$ & $E_{s}(\mathrm{GPa})$ & $f_{y}(\mathrm{MPa})$ & $f_{u}(\mathrm{MPa})$ \\
\hline 1.35 & 206 & 255 & 395 \\
1.75 & 206 & 275 & 405 \\
\hline
\end{tabular}

TABLe 2: Material properties of bamboo plywood.

\begin{tabular}{lcr}
\hline$t_{b}(\mathrm{~mm})$ & $E_{b}(\mathrm{MPa})$ & $\sigma(\mathrm{MPa})$ \\
\hline 15.1 & 4858 & 38 \\
17.6 & 6784 & 46 \\
25.0 & 6905 & 56 \\
\hline
\end{tabular}

Note: $t_{b}$ is the thickness of bamboo plywood.

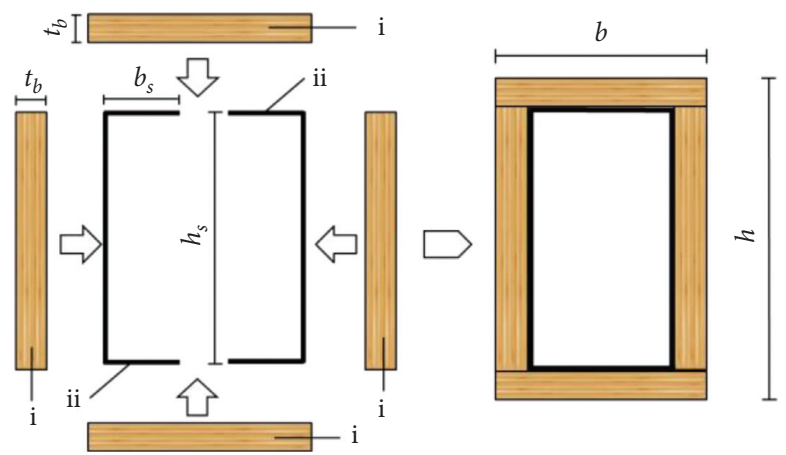

Figure 2: Section form of composite beam: (i) bamboo plywood and (ii) cold-formed thin-walled steel channel.

the midspan section (Figures 5(c) and 5(d)). The steel channel dimension of B-5 is larger than that of B-3. Unlike the B-3, the failure of B-5 attributed to the debonding between bamboo plywood and steel channel (Figure 5(e)), and local buckling of steel channel could be found near the support point (Figure 5(f)); thus, the specimen could not resist more load.

3.2. Load-Deflection Curves and Bearing Capacity. The loaddeflection curves for specimens B-1 to B-5 are shown in Figure 6 . The deflection here is the deflection of midspan, which is recorded by displacement sensor. As can be seen from Figure 6, the curves of each specimen could be divided into two stages, i.e., the elastic stage and elastic-plastic stage. During the elastic stage, the deflection of the specimen increased linearly with the increase of the load. At this stage, bamboo plywood and thin-walled steel worked together, and the overall performance of composite beam was good. Once the applied load reached approximately $50 \%$ of the ultimate load, the flexural stiffness of specimens gradually decreased due to the partial debonding of interface. The curves went into elastic-plastic stages, and the deflection of composite beam increased more, the load- 
TABLe 3: Parameters of specimens.

\begin{tabular}{lcccc}
\hline Specimens & $t_{b}(\mathrm{~mm})$ & $t_{s}(\mathrm{~mm})$ & $b_{s} \times h_{s}(\mathrm{~mm})$ & $b \times h(\mathrm{~mm})$ \\
\hline B-1 & 15.1 & 1.35 & $30.0 \times 135.0$ & $90.2 \times 165.2$ \\
B-2 & 25.0 & 1.35 & $30.0 \times 135.0$ & $110.0 \times 185.0$ \\
B-3 & 17.6 & 1.35 & $40.0 \times 135.0$ & $115.2 \times 170.2$ \\
B-4 & 17.6 & 1.75 & $40.0 \times 135.0$ & $115.2 \times 170.2$ \\
B-5 & 17.6 & 1.35 & $40.0 \times 175.0$ & $115.2 \times 210.2$ \\
\hline
\end{tabular}

Note: $b$ and $h$ represent the width and height of box section, respectively.

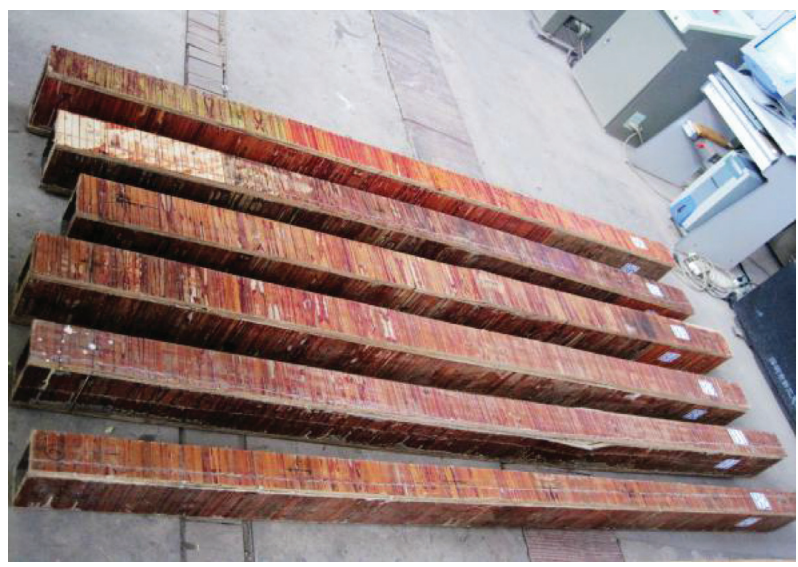

Figure 3: Specimens of composite beam. Note: one specimen was omitted due to the invalid result.

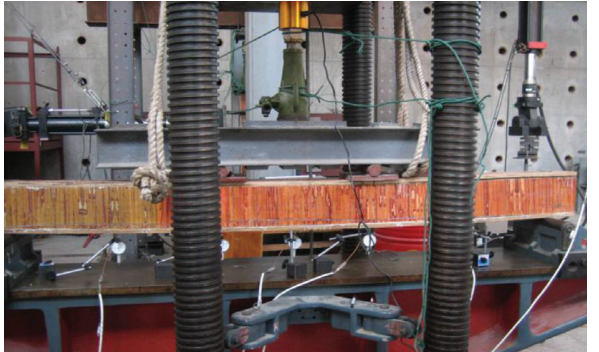

(a)

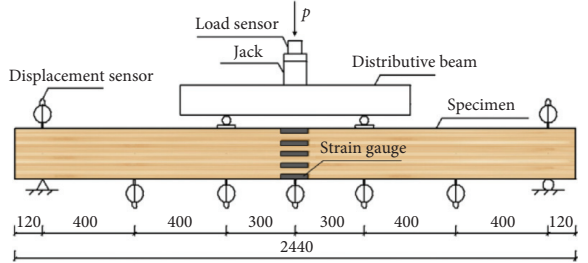

(b)

Figure 4: Test setup. (a) Photograph. (b) Diagrammatic view (all dimensions in mm).

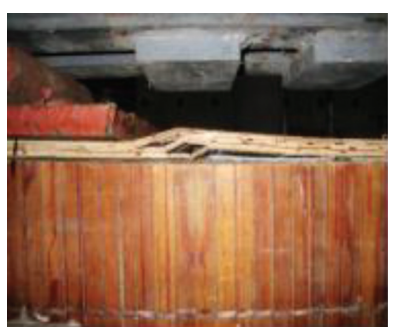

(a)

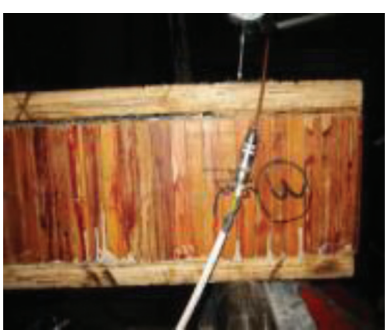

(b)

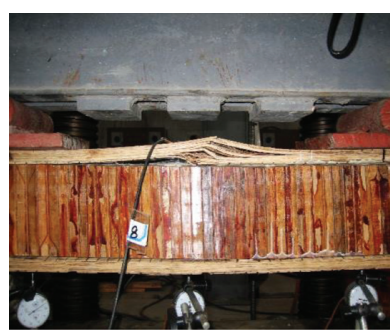

(c)

Figure 5: Continued. 


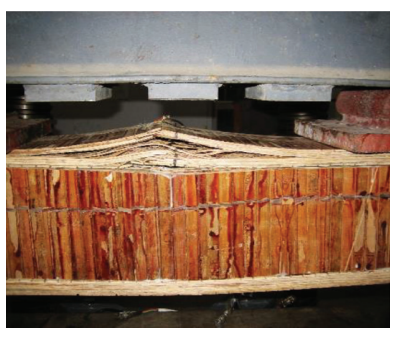

(d)

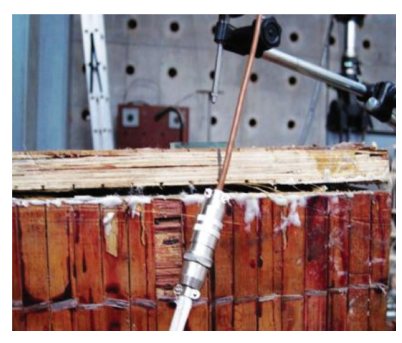

(e)

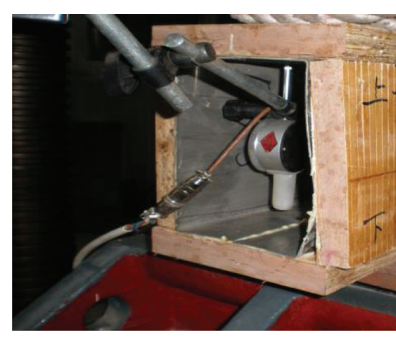

(f)

FIGURE 5: Failure characteristics of composite beams. (a) Extrusion of upper bamboo flange of B-1. (b) Debonding near support of B-2. (c) Extrusion of upper bamboo flange of B-3. (d) Extrusion of upper bamboo flange of B-4. (e) Debonding of B-5. (f) Local buckling near support of B-5.

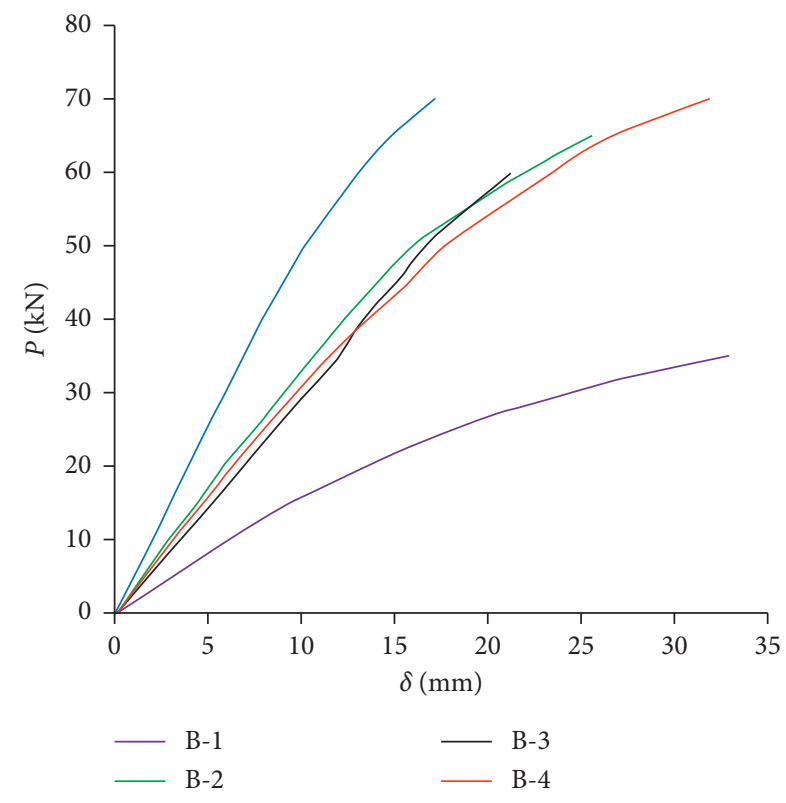

Figure 6: Load-deflection curves for specimens B-1 to B-5.

deflection curves showed nonlinear behaviour. There was no obvious descending section in each curve, and the load could keep near the ultimate load before the specimen failed. Thus, the composite beam had enough safety margin.

The limit state of members can be divided into two states, i.e., the ultimate limit state and the serviceability limit state. The members cannot meet the safety requirements when exceeding the ultimate bearing capacity. And the members cannot meet the suitability and durability requirements when exceeding the serviceability limit state. For flexural members, the flexural capacity calculation is controlled by the ultimate limit state, while the deflection calculation is controlled by the serviceability limit state. The bearing capacity of bamboo-steel composite flexural members (such as composite floors and composite beams) is high, and the deflection is also large. Thus, the bearing capacity under serviceability limit state is controlled by the rigidity condition. The deflection of box section bamboo-steel composite beam under serviceability limit state should be calculated by $1 / 250$ of span length according to the standard in China [22]. The main test results are shown in Table 4. The bearing capacity of composite beam under serviceability limit state is close to or exceeds half of that, under the ultimate limit state.

3.3. Strains Distribution at Midspan Section. Five strain gauges were arranged evenly at midspan of composite beams to measure the changes of strain along the height of beams under different loads. It was found that the cross-sectional strain curves of each beam were similar. Taking specimen B-3 as example, the average strain distribution along the height at midspan, which is shown in Figure 7, changed almost linearly, and the position of neutral axis of section was at the centre of beam height, which indicated that the midspan sectional deformation of the composite beam accorded with the plane-section assumption.

\section{Parametric Analysis}

4.1. Effect of Bamboo Plywood Thickness. The bamboo plywood thickness of B-2 was increased from $15.1 \mathrm{~mm}$ (thickness of B-1) to $25 \mathrm{~mm}$, as comparing B-1 and B-2, both of which had the same geometrical dimensions of the steel channel. Load-deflection curves (Figure 8) show that the ultimate load of B-2 was increased from $35 \mathrm{kN}$ of B-1 to $65 \mathrm{kN}$. And the deflection of B-2 was also significantly smaller than that of B-1 under the same load. This may attribute to the fact that the ticker bamboo plywood has great contribution to the sectional moment of inertia, which could improve the flexural stiffness and bearing capacity. Thus, with the increase of bamboo flange and web thickness of the composite beam, the ultimate load and flexural stiffness of composite beams can be greatly improved.

4.2. Effect of Thickness and Sectional Dimension of Steel Channel. The load-deflection curves of B-3 and B-4 are compared in Figure 9, and it can be found that the increased thickness of thin-walled steel can improve ultimate load and safety margin of composite beams, while having little effect on flexural stiffness. Because the sectional area of steel is far less than that of bamboo plywood in composite beams, the thicker steel channel has little contribution to the sectional moment of inertia. Thus, the thickness of steel channel has 
TABLE 4: Calculation results of specimens.

\begin{tabular}{lccccc}
\hline Specimens & $P_{u}(\mathrm{kN})$ & $M_{u}(\mathrm{kN} \cdot \mathrm{m})$ & $\delta_{\max }(\mathrm{mm})$ & $M_{u}^{\prime}(\mathrm{kN} \cdot \mathrm{m})$ & $\delta(\mathrm{mm})$ \\
\hline B-1 & 35.0 & 14.0 & 35.80 & 5.68 & 8.80 \\
B-2 & 65.0 & 26.0 & 25.47 & 11.40 & 8.80 \\
B-3 & 60.0 & 24.0 & 21.16 & 10.76 & 8.80 \\
B-4 & 70.0 & 28.0 & 31.76 & 11.72 & 0.41 \\
B-5 & 70.0 & 28.0 & 17.10 & 17.64 & 8.80 \\
\hline
\end{tabular}

Note: $P_{u}$ is the ultimate applied load; $M_{u}$ is the ultimate flexural bearing capacity; $\delta_{\max }$ is the deflection of midspan corresponding to $P_{u} ; M_{u}^{\prime}$ is the flexural bearing capacity in serviceability limit state; $\delta$ is the deflection of midspan in the serviceability limit state.

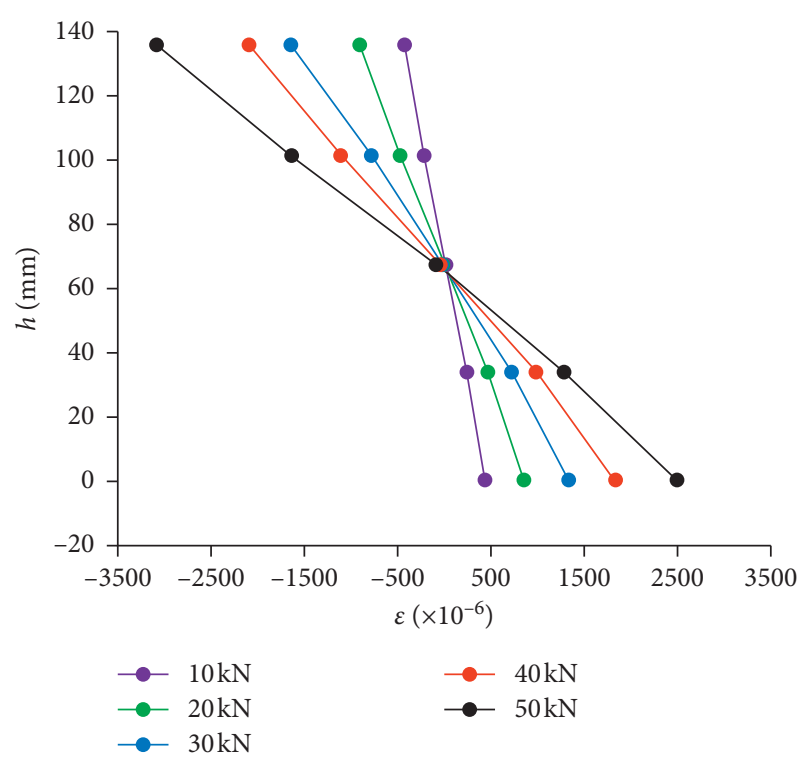

FIgURE 7: Strain distribution at midspan section of B-3.

little influence on the flexural stiffness of beams. However, the ultimate stress of steel $\left(f_{u}\right)$ is larger than the rupture modulus of bamboo plywood $(\sigma)$ according to Table 1 and Table 2. Therefore, the bearing capacity of the composite beam can be improved effectively by increasing the thickness of steel channel.

Similarly, the load-deflection curves of B-3 and B-5 are compared in Figure 10, and it can be found that the increase of the height of steel channel could improve the ultimate bearing capacity and flexural stiffness. That is because the increase of height of steel channel can increase both the inertia moment and area of cross-section effectively.

\section{Theoretical Calculation and Analysis}

5.1. Midspan Deflection. The test showed that the steel and bamboo plywood of the bamboo-steel composite beam are both in the elastic stage under the serviceability limit state. Therefore, superposition principle can be employed to calculate the flexural stiffness (EI) of the composite beam [2], which is given by

$$
\mathrm{EI}=E_{f b} I_{f b}+E_{w b} I_{w b}+E_{s} I_{s}
$$

where $E_{f b}, E_{w b}$, and $E_{s}$ are the elasticity modulus of flange bamboo plywood, web bamboo plywood, and steel channel, respectively; $I_{f b}, I_{w b}$, and $I_{s}$ are the inertia moment of flange

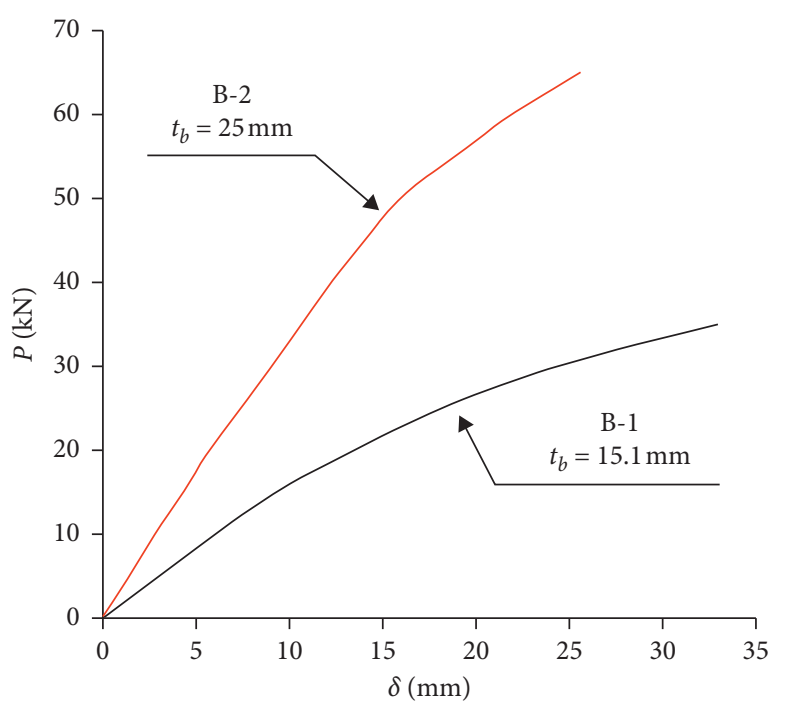

FIgURE 8: Effect of bamboo plywood thickness on load-deflection curves.

bamboo plywood, web bamboo plywood, and steel channel, respectively.

Considering the different deflection calculation of composite components between test and theory, a coefficient $\beta_{b}$ is introduced in the formula for calculating the midspan deflection of the simply supported beam [23]. Thus, the midspan deflection $(\delta)$ of the composite beam under the serviceability limit state can be expressed as follows:

$$
\delta=\beta_{b} \frac{\mathrm{pal}^{2}}{48 \mathrm{EI}}\left(3-4\left(\frac{a}{l}\right)^{2}\right),
$$

where the $P$ is the applied load on the composite beam, $a$ is the distance between the point of applied load and near support, $l$ is the calculated span of composite beam, and EI is the flexural stiffness of composite beam.

Figure 11 showed the comparison of midspan deflections between experimental values and theoretical values calculated by equation (1) and equation (2). It can be observed that the calculated values matched well with the experimental values with less than $10 \%$ relative errors.

5.2. Flexural Bearing Capacities. The test results showed that when the beam damaged, the upper flange of the crosssection was deboned, so the strength reduction factor $\gamma_{d}$ $\left(\gamma_{d}=0.95\right)$ [2] of bamboo plywood was introduced to 


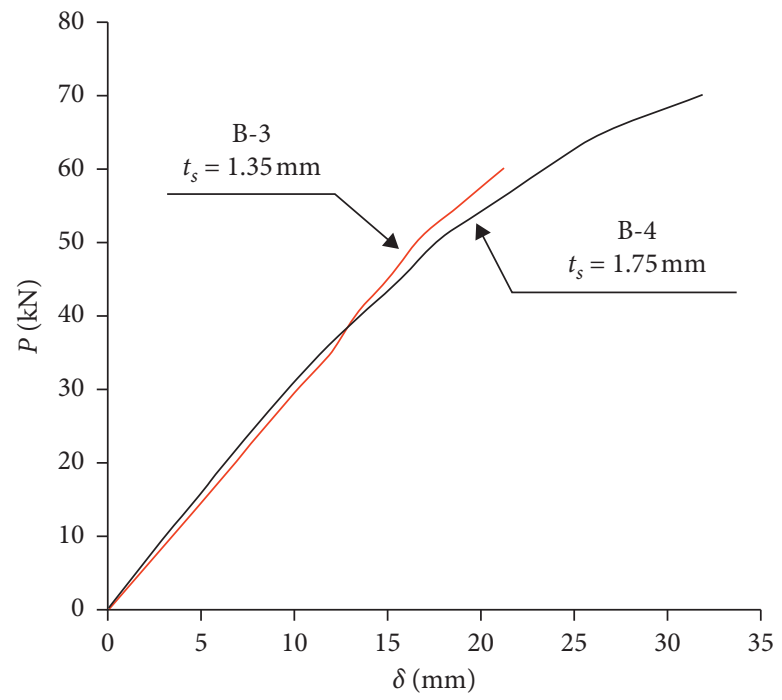

Figure 9: Effect of steel channel thickness on load-deflection curve.

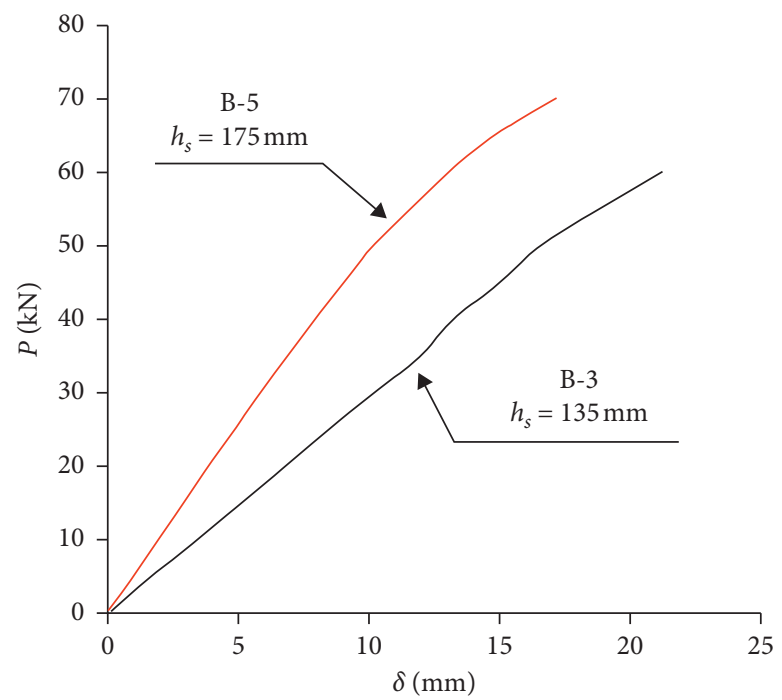

FIgURE 10: Effect of sectional dimension of steel channel on load-deflection curve.

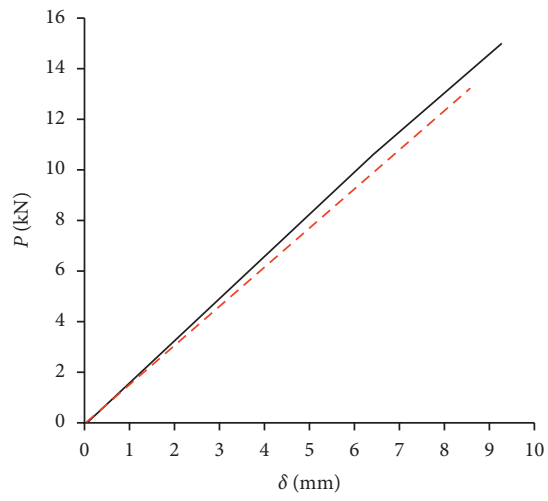

- Experimental value

- - - Calculated value

(a)

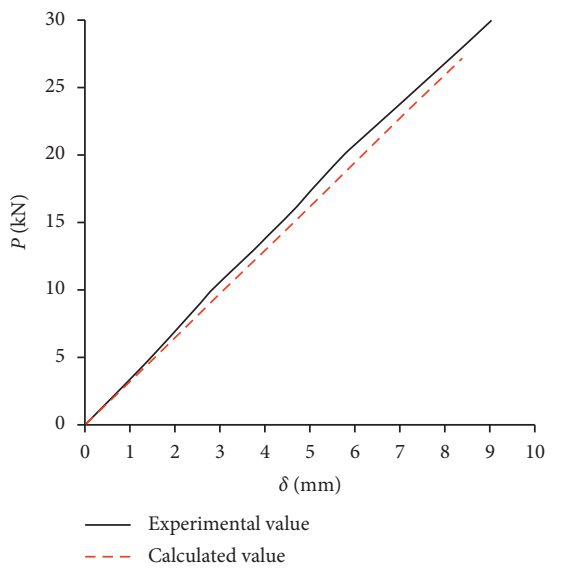

(b)

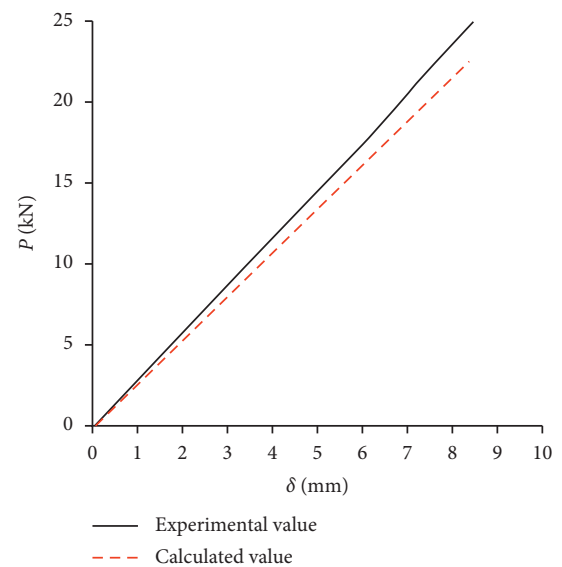

(c)

Figure 11: Continued. 


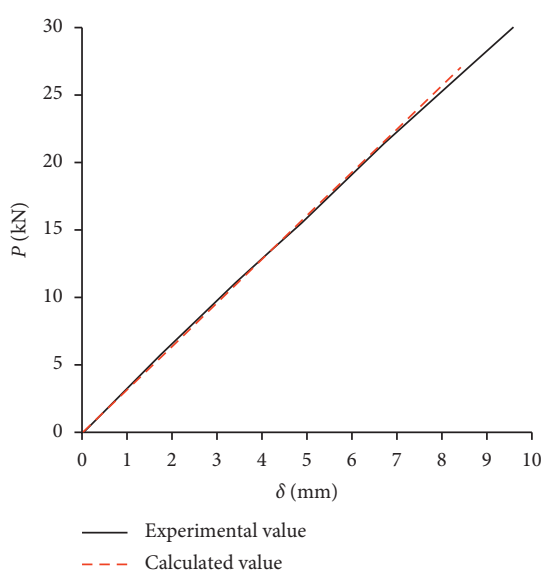

(d)

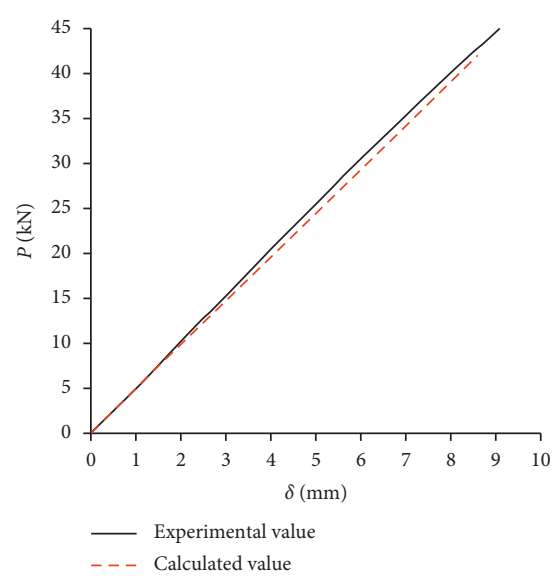

(e)

Figure 11: Comparisons of midspan deflections between the experimental and calculated value (in serviceability limit state). (a) B-1. (b) B-2. (c) B-3. (d) B-4. (e) B-5.

TABLE 5: Comparison of flexural bearing capacities between calculated and experimental values.

\begin{tabular}{lcccccc}
\hline Specimens & $M_{b}(\mathrm{kN} \cdot \mathrm{m})$ & $M_{s}(\mathrm{kN} \cdot \mathrm{m})$ & $M(\mathrm{kN} \cdot \mathrm{m})$ & $M_{\text {exp }}(\mathrm{kN} \cdot \mathrm{m})$ & $M_{b} / M$ & $M_{\text {exp }} / M$ \\
\hline B-2 & 5.10 & 7.65 & 7.65 & 12.75 & 14.00 & 0.40 \\
B-3 & 12.78 & 8.69 & 18.43 & 26.00 & 0.63 \\
B-4 & 10.04 & 13.53 & 25.54 & 28.00 & 0.10 \\
B-5 & 12.01 & 13.17 & 23.46 & 28.00 & 0.47 \\
B-6 & 10.29 & & & 0.44 & 1.27 \\
\hline
\end{tabular}

consider the debonding of upper flange. It also could be found that the strain of steel channel in the tension zone exceeded the yield strain $\left(\varepsilon_{s}>0.002\right)$ when the beam damaged, which indicated that the tension zone of the steel channel had reached the plastic stage while the other components were still in the elastic stage. Thus, the plastic ratio of steel channel $\gamma_{s}\left(\gamma_{s}=1.05\right)$ [24] was introduced to consider the plastic behaviour. Strain distribution at midspan section of specimens indicates that the midspan sectional deformation of specimens agrees with the planesection assumption. The flexural bearing capacities $(M)$ of box section composite beams are proposed based on the superposition principle, which is shown as follows:

$$
\begin{aligned}
M & =M_{b}+M_{s}, \\
M_{b} & =\gamma_{d} \sigma_{b} W_{b}, \\
\sigma_{b} & =\varepsilon_{b} E_{f b}, \\
M_{s} & =\gamma_{s} f_{u} W_{s},
\end{aligned}
$$

where $M_{b}$ and $M_{s}$ are the flexural bearing capacities of bamboo section and steel channel section, respectively; $\sigma_{b}$ and $\varepsilon_{b}$ are the failure normal stress and strain of bamboo plywood, respectively; $W_{b}$ and $W_{S}$ are the elastic section modulus of bamboo plywood section and steel channel section, respectively; and $f_{u}$ is the ultimate stress of steel channel.

The comparison of flexural bearing capacities between calculated values $(M)$ and experimental values $\left(M_{\exp }\right)$ are shown in Table 5. It can be found that the calculated capacities matched well with the experimental values. Furthermore, the bamboo section contributes $40-63 \%$ of the total flexural bearing capacity of composite beams.

\section{Conclusions}

In this paper, the flexural behaviour of box section bamboosteel composite beams was experimentally investigated and theoretically analysed. Five box section bamboo-steel composite beams were tested, and the conclusion based on the results is summarized as follows:

(1) The box section bamboo-steel composite beams have an excellent structural integrity, and no overall failures can be observed in the interface between bamboo plywood and thin-walled steel channel. The composite beams could combine the advantages of light weight and high strength of bamboo plywood and steel, while the disadvantage of easy buckling of thin-walled steel are overcome.

(2) The midspan cross-section strain curve of composite beams showed that strains changed linearly along the height of cross-section; therefore, the plane-section assumption can be used to study the composite beams.

(3) The thickness of bamboo plywood, thickness, and sectional dimension of steel channel have varying degrees influence on bearing capacities, flexural 
stiffness, and safety margin of the box section bamboo-steel composite beams. The bearing capacity and flexural stiffness increased with the increase of the thickness of bamboo plywood and sectional dimension of steel channel, while the thickness of steel channel has little influence on the flexural stiffness. However, the thickness of steel channel can improve bearing capacity and safety margin of composite beams.

(4) The bearing capacity of composite beams under serviceability limit state is close to or exceeds half of that, under ultimate limit state, which indicated that the strength of both bamboo plywood and thinwalled steel channel was fully utilized. The proposed equations for predicting the deformation and bearing capacities of composite beams matched well with the experimental results.

\section{Data Availability}

The data used to support the findings of this study are available from the corresponding author upon request.

\section{Conflicts of Interest}

The authors declare that there are no conflicts of interest regarding the publication of this paper.

\section{Acknowledgments}

The authors gratefully acknowledge the financial support provided by the National Key R\&D Program of China (2019YFD1101002), National Natural Science Foundation of China (NSFC) (51678310 and 51978345), and K. C. Wong Magna Fund at the Ningbo University.

\section{References}

[1] K. Wang, Q. Li, and X. Gao, "Present utilizational situation and deep exploitation of bamboo resources," Journal of Bamboo Research, vol. 19, no. 4, pp. 72-75, 2000.

[2] Y. Li, W. Shan, H. Shen, Z.-W. Zhang, and J. Liu, "Bending resistance of I-section bamboo-steel composite beams utilizing adhesive bonding," Thin-walled Structures, vol. 89, pp. 17-24, 2015.

[3] Y. Huang, Y. Qi, Y. Zhang, and W. Yu, "Progress of bamboo recombination technology in China," Advances in Polymer Technology, vol. 2019, Article ID 2723191, 10 pages, 2019.

[4] F. F. Wang and W. H. Wang, "The status quo and problems of bamboo-based panels production in China," China Woodbased Panels, vol. 14, no. 12, pp. 1-4, 2007.

[5] F. Z. Meng, W. J. Yu, and G. S. Chen, "Processing and properties comparison between four kinds of bamboo-based panel," Wood Processing Machinery, vol. 22, no. 1, pp. 32-35, 2011.

[6] A. Zhou and Y. Bian, "Experimental study on the flexural performance of parallel strand bamboo beams," The Scientific World Journal, vol. 2014, Article ID 181627, 6 pages, 2014.

[7] J. Lei, B. Chen, and P. Yuan, "Experimental study on flexural properties of side-pressure laminated bamboo beams,"
Advances in Civil Engineering, vol. 2020, Article ID 5629635, 10 pages, 2020.

[8] V. De Luca and C. Marano, "Prestressed glulam timbers reinforced with steel bars," Construction and Building Materials, vol. 30, pp. 206-217, 2012.

[9] Y. Wei, M. Zhou, and D. Chen, "Flexural behaviour of glulam bamboo beams reinforced with near-surface mounted steel bars," Materials Research Innovations, vol. 19, no. 1, pp. S198-S103, 2015.

[10] Y. Wei, X. Ji, M. Duan, and G. Li, "Flexural performance of bamboo scrimber beams strengthened with fiber-reinforced polymer," Construction and Building Materials, vol. 142, pp. 66-82, 2017.

[11] Y.-F. Li, Y.-M. Xie, and M.-J. Tsai, "Enhancement of the flexural performance of retrofitted wood beams using CFRP composite sheets," Construction and Building Materials, vol. 23, no. 1, pp. 411-422, 2009.

[12] Y. Nadir, P. Nagarajan, M. Ameen, and M. Arif M, "Flexural stiffness and strength enhancement of horizontally glued laminated wood beams with GFRP and CFRP composite sheets," Construction and Building Materials, vol. 112, pp. 547-555, 2016.

[13] H. Fang, X. Xu, W. Liu et al., "Flexural behavior of composite concrete slabs reinforced by FRP grid facesheets," Composites Part B: Engineering, vol. 92, pp. 46-62, 2016.

[14] Q. Lv, W. Wang, and Y. Liu, "Flexural performance of crosslaminated bamboo (CLB) slabs and CFRP grid composite CLB slabs," Advances in Civil Engineering, vol. 2019, Article ID 6980782, 17 pages, 2019.

[15] T. Liu, Y. Li, K. Xu et al., "Research on mechanical performance of steel-bamboo composite box short column," Industrial Construction, vol. 46, no. 1, pp. 25-29, 2016.

[16] Y. Li, H. Shen, W. Shan, L. Bo, and T. Jiang, "Experimental study on shear behavior of I-shaped section bamboo-steel composite beams," Journal of Building Structures, vol. 11, no. 7, pp. 80-86, 2011.

[17] Y. Li, W. Shan, Z. Huang, B. Ge, and Y. Wu, "Experimental study on mechanical behavior of profiled steel sheet-bamboo plywood composite slabs," Journal of Building Structures, vol. 29, no. 1, pp. 96-102, 2008.

[18] Y. Li, H. Shen, W. Shan, and T. Han, "Flexural behavior of lightweight bamboo-steel composite slabs," Thin-Walled Structures, vol. 53, pp. 83-90, 2012.

[19] Y. Li, H. Shen, W. Zhang et al., "Experimental study on seismic performance of compression plate and bamboo board composite wall," Engineering Mechanics, vol. s1, pp. 108-112, 2010.

[20] China National Standard, Metallic Materials-Tensile TestingPart 1: Method of Test at Room Temperature (GB/T228.12010), China National Standard, Beijing, China, 2010.

[21] China National Standard, Test Methods of Evaluating the Properties of Wood-Based Panels and Surface Decorated Wood-Based Panels (GB/T 17657-2013), China National Standard, Beijing, China, 2013.

[22] China National Standard, Standard for Design of Timber Structures (GB50005-2017), China National Standard, Beijing, China, 2017.

[23] China Architecture \& Building Press, Handbook of Static Calculation of Building Structures, China Architecture \& Building Press, Beijing, China, 2nd edition, 2000.

[24] China National Standard, Standard for Design of Steel Structures (GB 50017-2017), China National Standard, Beijing, China, 2017. 